\title{
Post-COVID-19 precautions based on lessons learned from past pandemics: a review
}

\author{
Prakash Mallappa Munnoli $^{1}$ (D) S. Nabapure ${ }^{2} \cdot$ G. Yeshavanth ${ }^{3}$ \\ Received: 4 June 2020 / Accepted: 10 July 2020 / Published online: 4 August 2020 \\ (C) Springer-Verlag GmbH Germany, part of Springer Nature 2020
}

\begin{abstract}
Aim In view of the spread of the contagious coronavirus disease (COVID-19) globally, the present review focuses on the details of past pandemic diseases, along with comparisons and lessons learned. A general awareness of COVID-19 infection is addressed, and it is compared with the Spanish flu pandemic. Based on the successes, failures and lessons learned in the past, governmental efforts must be undertaken to empower citizens by providing accurate information and implementing postCOVID-19 precautions that need to be taken now to stop the spread and recurrence of the virus locally, and to restore health and economic normalcy.

Methods A detailed literature survey of past pandemics is undertaken in order to extract the successes, failures and lessons learned from previous breakouts. The comparison of past pandemics will enable us to determine post-COVID-19 precautions that should be followed. Separate tables are prepared to highlight the lessons learned and measures to be taken. Both general precautions and preventive measures for pregnant women are compiled.

Results The literature shows a continuous struggle of humans with disease outbreaks, with the most adverse impact of the Spanish flu killing 20-50 million people. Precautions need to be taken including social distancing, compulsory mask-wearing, avoiding public gatherings and washing hands regularly. The lessons from earlier pandemics show that they were equally devastating, and vaccines were not available at the time of outbreaks. Vaccines developed for polio, H1N1, measles, and other viral diseases have proven to save countless lives. Living with COVID-19 and evolving the work culture of protecting oneself and protecting others also has to be adopted.

Conclusions COVID-19 has become an everyday topic of discussion throughout the world, indicating the increasing number of COVID-19 cases, deaths and recoveries. The lessons learned from past pandemics such as social distancing, wearing masks, avoiding public gatherings and adherence to guidelines, along with personal hygiene, are the key measures that must be taken in order to live with COVID-19. Precautions for the elderly and pregnant women advised by medical authorities are to be strictly adhered to. These will help in reducing COVID-19 cases and in turn will reduce the pressure on hospitals to serve those in need. India has learned lessons from the past and the present pandemic and will move towards growth through its self-reliance.
\end{abstract}

Keywords COVID-19 $\cdot$ Spanish flu $\cdot$ Pandemics $\cdot$ HIV/AIDS $\cdot$ Social distancing $\cdot$ Severe acute respiratory syndrome

Prakash Mallappa Munnoli munnolipm@gmail.com

1 Department of Civil Engineering, S D M College of Engineering and Technology, Dharwad 580002, India

2 Department of Obstetrics and Gynecology, Shamnur Shivashankarappa Institute of Medical Science and Research Center, Davangere 577004, India

3 Department of General Medicine, Shamnur Shivashankarappa Institute of Medical Science and Research Center, Davangere 577004, India

\section{Introduction}

Since the birth of civilisation, humans have experienced health issues due to changes in the quality of panch maha tatvas, i.e. Bhoomi (earth), Jal (water), Akash (sky), Agni (fire) and vayu (air), which adversely affect human health or well-being (Pevey et al. 2017). It has been written in the Vedas that these pancha tatvas have to be used and maintained in their purest state (Ahuluwali 2013). From the Antonine period until today, civilisations have lived with epidemics and pandemics, causing panic among people, who could only turn to for prayer for protection, causing economic destruction, and 
highlighting human mortality (Benedictow 2005; Scheidel 2017). Epidemics have regional effects whereas pandemics have worldwide effects of disease spread. The history of virology dates back to the identification of the first virus, the tobacco mosaic virus, in 1892 (Lecoq 2001; Nicklin et al. 2002), and has evolved since then with continuous development in virology studies using highly sophisticated microscopes (Baveja 2018; Pelczar et al. 1993). Nevertheless, governmental efforts are ongoing to improve the study of virology and microbiology in India, which is gaining in significance with the use of a multidisciplinary/integrated approach (Heymann et al. 2001) for developing vaccines and administering them to people for surveillance (http://www.who.int/ csr/response/publication/survillance/plague.pdf accessed on 25 May 2020). The effects of viral diseases like HIV/AIDS and other communicable diseases (Rashid et al. 2016; Davey 2016) and the subject of biology and microbiology have entered technical institutions (Mann 2012; Vale and Dell 2009), with a priority to be taught in all engineering courses to engender an understanding of social and healthy living.

\section{World history of pandemics}

The very first pandemic, based on the available literature, was the Antonine plague in $165 \mathrm{AD}$, and the most recent is coronavirus disease of 2019 (COVID-19). Pandemics presented chronologically include the Antonine plague (165 AD), Plague of Justinian (541-542 AD), Black Death (1346-1353), third cholera pandemic (1852-860) (http://www.cbc.ca/news/technology/cholera-s-seven-panemics-1.758504 accessed on 15 June 2020, flu pandemic (1889-1890), sixth cholera pandemic (1910-1911) (Collins 1996; Robert 1954), flu pandemic/ Spanish flu (1918) (Wever and Van Bergen 2014), Asian flu (1956-1958), flu pandemic (1968), Hong Kong flu (1981) (http://content.time.com/time/specials/packages/completelist/ 025969,2027479.00 acccessed on 15 June 2020), SARS (2002-2003), HIV/AIDS pandemic (2005-2012), swine flu (2009-2010), Ebola (2014-2016), MERS-CoV (2015), and COVID-19, an RNA virus disease. Each of these pandemics was a threat to mankind (Reid et al. 2004; Raj et al. 2020) and created panic in the absence of a vaccine at the time of the outbreak. The COVID-19 outbreak spread rapidly, claiming 2462 lives and infecting 78,811 just in the first month (Chowdhury et al. 2020), and the rate of mutation of the virus is higher than that of a DNA virus (Raj et al. 2020). In light of the current deadly pandemic, it was felt that a brief review of past pandemics was needed. A detailed list of the world's pandemics and their outbreak periods, number of deaths and countries affected, along with lessons learned from these outbreaks, is presented in Table 1. The spread of COVID-19 infection in persons around the globe has occurred at an alarming rate, with the World Health Organization (WHO) declaring it a public health emergency in January 2020 (Anonymous 2020; Kalteh and Rajabi 2020; Velavan and Meyer 2020). The world becomes a global village when it comes to surveillance of occurrence and recurrence of pandemic or endemic infectious disease (Heymann et al. 2001; Grein et al. 2000).

\section{Indian scenario}

India has witnessed in the recent past large outbreaks of emerging and re-emerging infectious diseases that have ravaged the resource-limited country (Robert 1959; David 1986; Suri and Sen 2011; Dikid et al. 2013). After successfully containing deadly outbreaks of Nipah virus and other high-threat pathogens, and building on the success in eliminating polio, India is now readying itself to address the threat of an influenza pandemic. The Ministry of Health and Family Welfare (MoHFW) and WHO jointly hosted a gathering of leading experts from the fields of public health, virology, epidemiology, surveillance, clinical medicine, One Health, disaster management, behavioural science, risk communication and the defence sector to identify and address challenges that India would face during an influenza pandemic (WHO Report 2014; Swetha et al. 2019).

The study of microbiology, and especially virology, is time-consuming, with many steps involved. The isolation, identification, preservation, characterisation, screening of antimicrobial activity (Parija 2016, and studying the behaviour of viruses in different laboratory conditions is both challenging and risky (Earnest Gould 1999). The challenges in developing new generations of vaccines are substantial at the levels of basic biology and efficacy. The greater challenges, howev$\mathrm{er}$, arise when introducing vaccines to the public (Rauch et al. 2018). Communities at large will resist any change in the natural system. For example, when family planning was introduced, people had misconceptions regarding different methods (Khan 1980). Similarly, acceptance of the polio vaccine by the population took several months before it became a routine procedure to eradicate polio (Chowdhary et al. 2011). There were continuous struggles for HIV/AIDS programs in India to bring about changes in public attitudes (Satyajeet and Pramanik 2009). It is not uncommon for India to experience sudden and rapid outbreaks of epidemics and pandemics. Studies have reported that outbreaks in developing countries are caused by malnutrition, lack of sanitation and proper public health systems, and unavailability of ready-made vaccines (Ergunay 2014; Rice et al. 2000; John et al. 2011; Sivabakya and Srinivas 2020). It is also a sad truth that India will have to be ready to face several more such outbreaks in the days to come (Mishra 2015). Thus, preparedness has to be given immense importance, and control of spread should be the number one priority of the government, doctors and other health care workers, and the general public. 
Table 1 Worst global pandemics, cause of transmission, countries involved, and lessons learned/measures to follow

\begin{tabular}{|c|c|c|c|}
\hline $\begin{array}{l}\text { Name of pandemic/ } \\
\text { period }\end{array}$ & Cause of transmission/deaths & Countries & Lessons learned/measures to follow \\
\hline $\begin{array}{l}\text { Antonine plague } \\
165 \mathrm{AD}\end{array}$ & Unknown/5 million & Anatolia, Egypt, Greece, Italy & $\begin{array}{l}\text { Believed to be outbreak of smallpox, appearance of boils } \\
\text { sounds like smallpox/no treatment }\end{array}$ \\
\hline $\begin{array}{l}\text { Plague of Justinian } \\
541-542 \mathrm{AD}\end{array}$ & Bubonic plague/25 million & $\begin{array}{l}\text { Constantinople, Eastern } \\
\text { Mediterranean }\end{array}$ & $\begin{array}{l}\text { Flea/insect control/sanitation of ports/ships } \\
\text { Overall personal hygiene; bacterial infection Yersinia pestis } \\
\text { transmitted through fleas }\end{array}$ \\
\hline $\begin{array}{l}\text { Black Death } \\
1346-1353\end{array}$ & $\begin{array}{l}\text { Bubonic plague } / 75-200 \\
\text { million }\end{array}$ & Asia, Africa, Europe & $\begin{array}{l}\text { Carried by fleas } \\
\text { Recurrence until twentieth century }\end{array}$ \\
\hline $\begin{array}{l}\text { Third cholera } \\
\text { pandemic } \\
1852-1860\end{array}$ & $\begin{array}{l}\text { Cholera/contaminated } \\
\text { water/1 million }\end{array}$ & $\begin{array}{l}\text { India, Asia, Europe, North } \\
\text { America, Africa }\end{array}$ & $\begin{array}{l}\text { Vibrio cholerae contaminated water } \\
\text { Treatment of water/daily monitoring of water quality parame- } \\
\text { ters }\end{array}$ \\
\hline $\begin{array}{r}\text { Flu pandemic } \\
1889-1890\end{array}$ & $\begin{array}{l}\text { Influenza A } \\
\text { virus/H2N2/H3N3/1 } \\
\text { million }\end{array}$ & $\begin{array}{l}\text { Central Asia, Canada, } \\
\text { Greenland }\end{array}$ & $\begin{array}{l}\text { Bed rest; ample fluids; nourishing food; treatment through } \\
\text { alcohol to quinine, salicylates }\end{array}$ \\
\hline $\begin{array}{l}\text { Sixth cholera } \\
\text { pandemic } \\
1910-1911\end{array}$ & Cholera/800,000 & $\begin{array}{l}\text { Middle East, North Africa, } \\
\text { Eastern Europe, Russia }\end{array}$ & $\begin{array}{l}\text { Transmitted through water contaminated with faeces and food; } \\
\text { disinfection of water; separating water supply lines from } \\
\text { human sewage; care for infants }\end{array}$ \\
\hline $\begin{array}{l}\text { Flu } \\
\text { pandemic/Spanish } \\
\text { flu } \\
1918-1919\end{array}$ & Influenza/20-50 million & $\begin{array}{l}\text { Europe, Australia, Africa, North } \\
\text { America }\end{array}$ & $\begin{array}{l}\text { Social distancing; wearing masks; avoid public gatherings; care } \\
\text { for health care workers, nurses, doctors, etc.; community } \\
\text { spread measures; quarantine; isolation; economy }\end{array}$ \\
\hline $\begin{array}{l}\text { Asian flu } \\
1956-1958\end{array}$ & Influenza/H2N2/2 million & $\begin{array}{l}\text { China, Singapore, Hong Kong, } \\
\text { USA }\end{array}$ & $\begin{array}{l}\text { Infections in children from schools; deadly to pregnant women } \\
\text { and elderly with existing lung and heart diseases; economy }\end{array}$ \\
\hline $\begin{array}{l}\text { Flu pandemic/Hong } \\
\text { Kong flu } \\
1968\end{array}$ & Influenza/H2N2/1 million & $\begin{array}{l}\text { Hong Kong, Singapore, } \\
\text { Vietnam/Philippines, India, } \\
\text { Australia, Europe, USA }\end{array}$ & $\begin{array}{l}\text { Human-to-human transmission } \\
\text { Social distancing; isolation; treatment with ample fluids; } \\
\text { nutritional food; economy }\end{array}$ \\
\hline $\begin{array}{l}\text { HIV/AIDS pandemic } \\
\text { 2005-2012 }\end{array}$ & HIV/AIDS/36 million & Africa, globally 131 countries & $\begin{array}{l}\text { Social distancing; no heterogeneous sex; use of condoms; } \\
\text { personal hygiene; challenge of bringing awareness; still } \\
\text { existing; economic pressure on developing countries }\end{array}$ \\
\hline $\begin{array}{l}\text { COVID-19 } \\
\text { pandemic } \\
2019-2020\end{array}$ & $\begin{array}{l}\text { Coronavirus } 2019 / 500,000 \\
\text { as of } 12 / 5 / 2020,613213 \\
\text { as of } 21 / 07 / 2020\end{array}$ & $\begin{array}{l}\text { China, Europe, USA, South } \\
\text { America, Africa, Gulf } \\
\text { countries, Russia }\end{array}$ & $\begin{array}{l}\text { Characteristics of virus are changing } \\
\text { Fast-spreading; symptoms appear after } 6 \text { to } 7 \text { days } \\
\text { Preparedness; decision-making } \\
\text { Social distancing; masks; separate elderly from children } \\
\text { No public gatherings } \\
\text { Learn to live with it with full precautions }\end{array}$ \\
\hline
\end{tabular}

Source: WHO Reports (2010, 2020); Jordan and Robert (2011); Shanks (2015); Gupta et al. (2017); Jamison et al. (2006); Kempińska and Woźniak (2013); Mourya et al (2019); http://www.infoplease.com/cig/dangerous-disease-epidemics/bublonic plague.html accessed on $16 \mathrm{June} 2020$; http://www.mpholine.org/worst-pandemics-in-history accesed on 25/May 2020

\section{Post-coronavirus effects}

The novel coronavirus COVID-19 that originated in Wuhan, China (Zhou et al. 2020; Chowdhury et al. 2020) is showing its severity in the form of new human-to-human transmission (Bhattacharya et al. 2020) and has now become a global concern (Hassan et al. 2020; Mothay and Ramesh 2020; Yaseen et al. 2020). The present COVID-19 pandemic, with its first case
Table 2 Characteristics of SARSCoV-2 (COVID-19)

\section{Origin}

Type of virus

Flow of information

Transmission

Incubation period

Symptoms
Wuhan, China; suspected to be from bats

RNA virus; obligate parasite

\section{RNA-DNA-RNA}

Human-to-human; nosocomial; eyes

2-14 days

Fever; scratchy throat; dry cough; shortness of breath; breathing difficulties

SARS severe acute respiratory syndrome

Source: Yaseen et al. (2020), Chowdhury et al. (2020) 
reported in India on 30 January 2020, has a severity in terms of attacking the respiratory system (Table 2), especially in persons aged 50 and above.

A total of $15,099,458 / 1 / 1,194,888$ and $619,605 / 28,771$ cases of infection/deaths have been reported worldwide and in India, respectively, as of 03/07/2020 (https:// www.worldometers.info/coronavirus accesses on 22 May 2020). The infection continues to spread due to its contagious nature (Lessler et al. 2009), with the path of human-tohuman transmission through respiratory droplets (WHO 2020) and variable incubation time for symptoms to appear (Hawker et al. 2008). Another prevalent issue is that COVID19 features are similar to those of common influenza viruses causing colds. The most common feature of common influenza viruses is seasonality, which implies that influenza caused by viruses increases during colder temperatures, and then subsides with warming of the air temperature. By analysing the data up to 7 March 2020 and by considering more than 80 locations comprising a number of confirmed cases and location-specific meteorological data, we showed that the spread of the virus is strongly dependent on the temperature and UV index (Nair and Neel 2020; Gunthe et al. 2020).

There is a long way to go before we will be able to say that COVID-19 is completely eradicated (Islam et al. 2020). People may have to live with it for some time and resist infection by following strict guidelines of social distancing and hygiene, as too great an economic imbalance (Nicola et al. 2020) will pose many other problems such as increased poverty (Balaji and Sravendra 2020), death due to hunger and malnutrition, and increased numbers of homeless (Banerjee and Bhattacharya 2020). From a business point of view, the retooling of production with new policies of safe social distancing and fewer workers will pose different challenges (Dasgupta and De 2020; Ramteke 2020). The phased lifting of restrictions on people's travel to work is also a concern (Page 2020). Disruptions in the academic setting at institutions of higher learning and difficulties in conducting online classes affect the educational system (Singh 2020), and rural students without available Internet facilities are deprived of their learning. In addition, the transfer of people who are stranded due to the lockdown and additional administrative responsibilities are placed on government officers for control and movement of the public, such as issuance of passes and maintaining law and order (Khanna et al. 2020).

With great disruption and number of deaths ranging from 20 to 50 million, the Spanish flu (1918-1919) that occurred over 100 years ago appeared in three successive waves. Therefore, particular emphasis was given to reviewing the literature on the Spanish flu to understand the lessons learned.

The first established cases in the history of the so-called Spanish flu occurred on 4 March 1918, and within a span of 21 days, 1000 soldiers were infected with the fever (Phillips 2014; Mercer 2014; Tsoucalas et al. 2015). In Europe, the disease spread through France, Great Britain, Italy and Spain, causing havoc with military efforts in the First World War. In May, the flu spread to North Africa and Bombay, India, in June to China, and in July to Australia (Radusin 2012a; Krammer et al. 2018). The second wave spread from North America to Central and South America, and from Freetown, West Africa to South Africa and the Horn of Africa in November 2019. The flu had spread to almost all of Europe, Poland and Russia, northern Asia, India and China (Radusin 2012b). The third wave of the Spanish flu hit Australia in December 1918, New York in January 1919, Paris and Japan in December 1919, and ended in January 1920 (Taubenberger and Morens 2006; Martin et al. 2019; Tsoucalas et al. 2015).

COVID 19 has shown initial signs of recurrence in Wuhan, China, and infections are occurring in other countries at an alarming rate, with few countries showing a decreasing number of cases. Therefore, living with COVID-19 while taking the utmost precautions must be given the highest priority to draw a balance between the economy and health.

\section{Integrated approach to fighting COVID-19}

Simultaneously undertaking a technological, social and legislative approach proved to be successful in flattening the curve of positive cases and deaths during the first 100 days of the pandemic. The steps taken by the government of India include (1) the 'Janata Curfew' 14 March 2020, (2) lockdown from 24 March to 14 April 2020, and (3) continued lockdown from 15 April to 3 May 2020 (Mandal et al. 2020).

The Ministry of Family Welfare of the Government of India has set forth guidance for fighting COVID-19. The strategy involves establishing three types of facilities: fever clinic/ COVID care centre (CCC), dedicated COVID health centre (DCHC) and dedicated COVID hospital (DCH). The roles played by these centres and facilities are presented in detail in Table 3.

Plasma technology Plasma technology is now being considered as an alternative. Blood is collected from a person who has recovered from COVID-19. Separation of serum and screening is done for virus-neutralising antibodies. Convalescent serum, rich in antibodies for the pathogen, is then administered to a COVID-19 patient, who thus acquires passive immunity (Ivan et al. 2011; Duan et al. 2020; Bethany and Mc Cullough 2020; Paital et al. 2020; Singhal 2020).

India is known for its millets throughout the world, and the nutrition they provide is of great significance to human immune system growth (Sarkar et al. 2015). Millets (more recently known as nutri-cereals) are nutritionally superior to major cereals (wheat and rice) for carbohydrates and energy, and serve as a good source of protein, high dietary fibre, vitamins, minerals, antioxidants and micronutrients, as VA 
Table 3 Guidance document on appropriate management of suspect/confirmed cases of COVID-19

\begin{tabular}{|c|c|c|c|}
\hline Types of COVID-19-dedicated facility & Functions/care & Human resources and transport facilities & $\begin{array}{l}\text { Mapped } \\
\text { to }\end{array}$ \\
\hline $\begin{array}{l}\text { COVID care centre (CCC): } \\
\text { Hostel, hotel, school, lodge, etc. Separate rooms for } \\
\text { suspected and non-COVID-19 patients }\end{array}$ & $\begin{array}{l}\text { Temperature, respiration, oxygen level and } \\
\text { other symptoms } \\
\text { Mild and very mild cases and COVID-19 } \\
\text { suspected cases: treatment }\end{array}$ & $\begin{array}{l}\text { Doctors, nurses with makeshift personal } \\
\text { protective equipment (PPE) } \\
\text { Basic life support ambulance (BLSA) }\end{array}$ & $\begin{array}{l}\mathrm{DCHC} \\
\mathrm{DCH}\end{array}$ \\
\hline $\begin{array}{l}\text { Dedicated COVID-19 health centre (DCHC): } \\
\text { Private hospital with separate entry/exit/zones }\end{array}$ & $\begin{array}{l}\text { Suspected cases with moderate symptoms: } \\
\text { treatment } \\
\text { Symptoms worsen from moderate to } \\
\text { severe: transfer the patient to DCH }\end{array}$ & $\begin{array}{l}\text { Doctors and nurses/attendants with } \\
\text { makeshift PPE } \\
\text { Beds with oxygen support } \\
\text { Basic life support ambulance }\end{array}$ & $\mathrm{DCH}$ \\
\hline $\begin{array}{l}\text { Dedicated COVID-19 hospital (DCH): } \\
\text { Full hospital with separate entry/exit/zones } \\
\text { separate rooms for confirmed/suspected cases }\end{array}$ & $\begin{array}{l}\text { To deal Severe } \\
\text { Clinically assigned as severe }\end{array}$ & $\begin{array}{l}\text { Doctors/nurses/attendants with } \\
\text { makeshift PPE } \\
\text { Intensive care unit with ventilators/beds } \\
\text { with assured oxygen supply }\end{array}$ & $\begin{array}{l}\mathrm{DCHC} \\
\mathrm{DCH}\end{array}$ \\
\hline
\end{tabular}

Source: Ministry of Health and Family Welfare 2020 Government of India

Tonapi, Director of the IIMR-ICAR, has noted (The Hindu Business Line dated 28/04/2020).

General post COVID-19 guidelines and precautions for pregnant women, mothers and their newborns during and after the pandemic are presented in Table 4.

People have to choose to live like the ancient Indians lived, with cultural distancing and behaviour, while also working to build the economy through new frontiers in engineering, technology, medicine and agriculture, with continuous research on virology. The country must be ready to face any kind of situation and medical emergency. The production of indigenously developed ventilators, homemade masks, etc., along with governmental efforts to increase the capacity of hospitals and doctors, should be given priority. The COVID-19 pandemic can be been viewed as a crisis opportunity for the development of India.

\section{Other preventive medicines}

Ashwagandha The properties of the ayurvedic herb ashwagandha have 'therapeutic and preventive value' against
COVID-19 infection, researchers of IIT-Delhi have found, in collaboration with Japan's National Institute of Advanced Industrial Science and Technology (AIST). The researchers, led by Professor D. Sundar from the DBT-AIST International Laboratory for Advanced Biomedicine (DAILAB), said their study had been accepted for publication in the Journal of Biomolecular Structure and Dynamics, and was likely to be published soon, according to The Indian Express, Tuesday, 19 May 2020.

In a recent positive development, the Ministry of Ayush, in collaboration with the Council of Scientific and Industrial Research (CSIR), has started clinical trials testing formulations of four important Ayurvedic herbs in fighting the novel coronavirus. The medicines under study include ashwagandha, guduchi, yasthimadhu, peepli, and another formulated drug, 'Ayush 64' (https://www.ayush. gov.in/).

The trials, which will first be carried out among health workers, will be initially conducted in high-risk zones identified by the Arogya Setu application. It is reported that over 50

Table 4 Post-COVID-19 general guidelines and precautions for pregnant women, mothers and their newborns during and after the pandemic

\begin{tabular}{lll}
\hline Protection against infection & Pregnant women, new mothers and babies & Newborn care \\
\hline Avoid close contact & Avoid crowded places & Baby and mother together \\
Avoid touching mouth and nose & Avoid caring for confirmed cases & Support breastfeeding \\
Wash hands & Avoid caretakers with respiratory syndrome & Minimum contact with health workers \\
Avoid crowded places & Give vaccination to pregnant women & Screening facilities for visitors \\
Air flow through windows & Protect infants from viral infection & Limit visitors \\
Adequate sleep & Wash hands & Child handling procedure \\
Eating nutritious food & Keep environment clean & Vaccinations \\
Staying physically active & Use masks & Consult child specialist \\
Always to be under medical supervision & Keep newborn close to mother & Limit visitors at home
\end{tabular}

Source: WHO Reports $(2007,2009 a, b, c, 2010)$ 
lakh people from cities including Delhi, Mumbai, Ahmedabad and Pune will be a part of the clinical trial. The Ayush ministry is also studying the impacts of Ayush-based prophylactic interventions in some preventive cases. In the first phase, patients are likely to be administered ashwagandha, and later the other drugs will be given to patients, depending on how they react or the severity of the symptoms (Times of India.com 12 May 2020).

The Ayush Ministry has recommended homeopathy and Unani medicines as effective in the prevention of COVID19. As reported by the Economic Times Healthworld.com on 19 January 2020, the Central Council for Research in Homeopathy (CRRH) suggested that Arsenicum album 30 could be taken on an empty stomach daily for 3 days as a prophylactic medicine against COVID-19 infection. The dose should be repeated after 1 month if cases of COVID-19 are prevalent in the community.

The Ayush Ministry and MoHFW suggested good personal hygiene practices including wearing of masks, avoiding public gatherings, washing hands with soap for at least $20 \mathrm{sec}-$ onds, avoiding touching the nose, eyes and mouth with unwashed hands, and avoiding close contact with people who are sick, as also advocated by WHO 2020.

Sanders et al. 2020 reported that the COVID-19 pandemic caused by the novel severe acute respiratory syndrome coronavirus 2 (SARS-CoV-2) presents an unprecedented challenge in identifying effective drugs for prevention and treatment. Given the rapid pace of scientific discovery and clinical data generated by the large number of people rapidly infected by SARS-CoV-2, clinicians need accurate evidence regarding effective medical treatments for this infection.

No proven effective therapies for this virus currently exist. The rapidly expanding knowledge regarding SARS-CoV-2 virology provides a significant number of potential drug targets. The most promising therapy is remdesivir (Amirian and Levy 2020). Remdesivir has shown potent in vitro activity against SARS-CoV-2, but it is not yet approved for this indication by the US Food and Drug Administration and is currently being tested in ongoing randomised trials. Oseltamivir has not been shown to have efficacy (Muralidharan et al. 2020), and corticosteroids are currently not recommended. Current clinical evidence does not support stopping angiotensin-converting enzyme inhibitors or angiotensin receptor blockers in patients with COVID-19 (Patel and Verma 2020). The following four treatments are commonly advised to be given to all COVID-19 patients to boost general immunity: (1) vitamin $\mathrm{C}$ in warm water with half a lemon at regular intervals, (2) balls of dry ginger, jaggery and ghee three times a day, (3) turmeric in hot water (acts as an anti-coronavirus agent), 4) steam treatment at least once a day (Bucher and White 2016; WHO Coronavirus 2020; (http://www.nanavatihospital.org acccessed on 22 May 2020; http://www.thehindubusinessline.com/economy/ agri-business/strong-immunity-is-a-key-weapo-in-the-fight-
against-Covid-19/article 31453126.ece accessed on 16 May 2020).

Israel is advocating the separation of the elderly and children to minimise the spread of COVID-19, whereas 6 feet social distancing is being specified by the WHO 2020. China's success comes from a complete lockdown of Wuhan. India, on the frontline, took an early decision to flatten the disease curve and engaged in generating as much awareness as possible in both urban and rural areas, before slowly opening up the economy. Angela Betsaida B. Laguipo, a registered nurse writing in News Medical Life Sciences, reported on lessons learned from the Italian COVID-19 outbreak, including the impact of COVID19 on the regional and national healthcare infrastructure (http:// www.news-medical.net/medical/authors/angela-betsaidalaguipoaccessed on 28 May 2020). Included in the study are recommendations based on the experiences of doctors, nurses and healthcare personnel in managing patients in the country (https://www.news-medical.net/news/ 22 June 2020). The team highlighted the key elements needed in the clinical management of the viral infection, including safe oxygen therapy, airway management, personal protective equipment and non-technical aspects of patient care.

Alex Shankland, a research fellow, in his opinion piece 'Lessons from Brazil for the global response to COVID-19' published by the Institute of Development Studies on 25 March 2020, notes the strengths on which Brazil's health and social protection systems can draw in enabling responses to the COVID-19 pandemic to avoid worsening existing health inequities (http://www.ids.ac.uk/openions/lessons-from-brazilfor-the global-response-to-Covid-19/ accessed on 28 May 2020). These include the depth and breadth of the country's community-based primary care network, the national coverage of cash transfer schemes such as Bolsa Família, and the innovative institutional arrangements that have enabled state, civil society and private sector actors to coordinate responses to previous epidemics (https://www.ids.ac.uk/opinions/lessons-from-brazil-for-the-global-response-to-covid-19/).

There is great experience in every country as far as the fight against COVID-19 is concerned. A combined effort to collect all these experiences and lessons learned from almost 213 countries will be a resource for future preparedness in terms of medical infrastructure, handling of quarantine centres, COVID-19 care centres, COVID-19 care hospitals, medicines, personal care equipment, movable infrastructure, masks for frontline workers and working people, guidelines for social distancing, doctors, nurses, Asha village health workers, maintenance personnel and legislative support. The most important is people's participation in all health care programs and strict adherence to guidelines (Vanita 2020).

Amidst the spread of COVID-19 and its devastating effects on populations worldwide, and with the economies of most countries in a recession, it is now a global challenge for all countries to focus on balancing health and economic 
concerns, as they both affect the prosperity and well-being of society. People have to understand the situation and fully cooperate with the government and COVID-19 warriors who have been working tirelessly from day one. Let us end this review by acknowledging the respect that is due every individual who is contributing to the fight against COVID-19, and hope to see all activity return to normal, and the world as a global village will be in peace.

\section{Conclusions}

COVID-19 has become an everyday topic of discussion throughout the world, indicating the increased number of COVID-19 cases, deaths and recoveries. The lessons learned from past pandemics including social distancing, wearing masks, avoiding public gatherings and following guidelines, along with one's own personal hygiene, are the key points to living with COVID-19. The precautions for the elderly and pregnant women as per the medical authorities are to be strictly adhered to. These will help to reduce COVID-19 cases and in turn reduce the pressure on hospitals to serve those in need. India has learned lessons from the past and present pandemic and will move towards growth through its self-reliance.

Acknowledgements We sincerely thank Poojya Dr. Veerendra Heggade, President SDME Society Ujire, for his support and encouragement to undertake community works. The authors also thank Dr. B. Yashovarma and Shri Jeevandhaar Kumar for their encouragement during Unnat Bharat Abhiyan community project works. We thank our Principal Dr. K Gopinath for his support in undertaking the adoption of COVID-19 awareness programs in the villages.

Authorship statement The corresponding author conceived of the idea for the review and has studied various past pandemic literature, and formulated the paper. The second author contributed from the perspective of her field of gynecology and looked into the precautions for pregnant women and infants under the COVID-19 situation. The third author from the field of general medicine has made substantial contributions in reviewing and giving suggestions for improvement.

\section{Compliance with ethical standards}

Ethical statement The authors declare that no ethical approval was necessary for this research work.

Conflict of interest The authors declare that they have no conflict of interest.

\section{References}

Ahuluwali BS (2013) Inspired life: mantras for life. Partidge Publishing, New Delhi

Amirian ES, Levy JK (2020) Current knowledge about the antivirals remdesivir (GS-5734) and GS-441524 as therapeutic options for coronaviruses. One Health. https://doi.org/10.1016/j.onehlt.2020. 100128

Anonymous (2020) Letter to the editor, Japan ECMOnet for COVID-19. J Intensive Care 8:24. https://doi.org/10.1186/s40560-020-00440-9

Balaji K, Sravendra R (2020) COVID 19 in India: strategies to combat from combination threat of life and livelihood. J Microbiol Imunolo Infect 53(3):389-391. https://doi.org/10.1016/j.jmii.2020.03.024

Banerjee D, Bhattacharya P (2020) The hidden vulnerability of homelessness in the COVID-19 pandemic: perspectives from India. Int J Soc Psychiatry. https://doi.org/10.1177/0020764020922890

Baveja CP (2018) Text book of microbiology, 6th edn. Arysa Publications, New Delhi, pp 1-100

Benedictow O (2005) The Black Death: the greatest catastrophe ever. Hist Today 55(3):42-49

Bethany LB, Mc Cullough J (2020) Treatment for emerging viruses: convalescent plasma and COVID-19. Transf Apheres Sci. https:// doi.org/10.1016/j.transci.2020.102790

Bhattacharya S, Sharma P, Mathur H et al (2020) Recent apprise on coronavirus and its terrible insinuations. VirusDisease. https://doi. org/10.1007/s13337-020-00582-2

Bucher A, White N (2016) Vitamin C in the prevention and treatment of the common cold. Am J Lifestyle Med. 10(3):181-183. https://doi. org/10.1117/1559827616629092

Chowdhary P, Thacker N, Gargano LM, Paul SW, Vipin MV (2011) Attitudes and perception of private pediatricians regarding polio immunisation in India. Vaccine 29(46):8317-8322

Chowdhury A, Juhani N, Wang S (2020) One month of the novel coronavirus 2019 outbreak: is it still a threat? VirusDisease. https://doi. org/10.1007/s13337-020-00579-x

Collins AE (1996) The geography of cholera. In: Cholera and the ecology of Vibrio cholerae. Springer, Dordrecht, pp 255-294

Dasgupta P, De O (2020) Sustainable recovery with Jobs and more: this is a pandemic, not a war. Fighting COVID-19: assessments and reflection. 61

Davey B (2016) Public health approaches to infectious disease

David A (1986) Cholera and colonialism in British India. Past Present 113:118-151

Dikid T, Jain SK, Sharma A, Kumar A, Narain JP (2013) Emerging and re-emerging infections in India: an overview. Indian J Med Res 138(1):19-31

Duan K et al (2020) Effectiveness of convalescent plasma therapy in severe COVID-19 patients. Proc Natl Acad Sci USA 117:94909496. https://doi.org/10.1073/pnas.2004168117

Ergunay K (2014) Phelbeotomus Fewer - San fly fewer, emerging infectious diseases. Science Direct pp 149-162

Grein TW, Kamara KB, Rodier G et al (2000) Rumors of diseases in the global village: outbreak verification. Emerging Infect dis 6(2):97102. https://doi.org/10.3201/eid0602.000201

Gloud EA (1999) Methods of long-term preservation. Molecular biotechnology 1:13(1):57-66

Gunthe, SS Swain B, Patra SS, Amte A (2020) On the global trends and spread of the COVID-19 outbreak: preliminary assessment of the potential relation between location-specific temperature and UV index. J Public Health. https://doi.org/10.1007/s10389-020-01279-y

Gupta A, Ray S, Tyagi R, Kumar A (2017) Control of H1N1 influenza outbreak: a study conducted in a naval warship. J Mar Med Soc 19: $142-145$

Hassan S, Sheikh FN, Jamal S et al (2020) Coronavirus (COVID-19): a review of clinical features, diagnosis, and treatment. Cureus 12(3): e7355. https://doi.org/10.7759/cureus. 7355

Hawker J et al (2008) Communicable disease control handbook. Wiley, Hoboken

Heymann DL, Rodier GR, The WHO Operational Support Team to the Global Outbreak Alert and Response Network (2001) Hot spots in a wired world: WHO surveillance of emerging and re-emerging infectious diseases. Lancet Infect Dis 1:345-353 
Islam A, Ahmed A, Naqvi IH et al (2020) Emergence of deadly severe acute respiratory syndrome coronavirus-2 during 2019-2020. VirusDisease

Ivan $\mathrm{H}$ et al (2011) Convalescent plasma treatment reduced mortality in patients with severe pandemic influenza A (H1N1) 2009 virus infection. Clin Infect Dis 52(4):447-456. https://doi.org/10.1093/cid/ ciq106

Jamison DT, Breman JG, Measham AR et al (eds) (2006) Disease control priorities in developing countries, vol 2006, 2nd edn. The International Bank for Reconstruction and Development/the World Bank, Washington DC

John TJ, Dandona L, Sharma VP, Kakkar M (2011) Continuing challenge of infectious diseases in India. Lancet 377(9761):252-269

Jordan WT, Robert VT (2011) Lessons learned during public health response to cholera epidemic in Haiti and the Dominican Republic. Emerging Infect Dis 17(12):2399

Kalteh EA, Rajabi A (2020) COVID-19 and digital epidemiology. J Public Health (Berl.). https://doi.org/10.1007/s10389-020-01295-y

Kempińska MB, Woźniak KA (2013) The influenza epidemic of 1889-90 in selected European cities-a picture based on the reports of two Poznań daily newspapers from the second half of the nineteenth century. Med Sci Monit 19:1131-41. https://doi.org/10.12659/ MSM.889469

Khan ME (1980) Determinants of strelization in India. In A I Hermalin and B Entvisle (eds.), The role of survey in the analysis of family planning programs. Liege Belgium: Ordina Editions

Khanna R, Cicinelli M, Gilbert S, Honavar S, Murthy G (2020) COVID19 pandemic: lessons learned and future directions. Indian J Ophthalmol 68(5):703-710

Krammer F, Smith GJD, Fouchier RAM, Peiris M, Kedzierska K, Doherty PC, Palese P, Shaw ML, Treanor J, Webster RG (2018) Influenza. Nat Rev Dis Primers 4(1):3

Lecoq H (2001) Discovery of the first virus, the tobacco mosaic virus: 1892 or 1898. C R Acad Sci III 324(10):929-933

Lessler J et al (2009) Incubation periods of acute respiratory viral infections: a systematic review. Lancet Infect Dis 9(5):291-300

Mandal S, Kumar M, Sarkar D. (2020) Lockdown as a pandemic mitigating policy intervention in India. medRxiv. https://doi.org/10. 1101/2020.06.19.20134437

Mann DD (2012) The Role of Biology in an Engineering Program Department of Bio-systems Engineering, University of Manitoba, Winnipeg, MB R3T 5V6: Proc. 2012 Canadian Engineering Education Association (CEEA12) Conf. CEEA12; Paper 066 Winnipeg, MB; June 17-20, 2012-1 of 5

Martin M, Gazzaniga V, Bragazzi NL, Barbaris I (2019) Spanish influenza pandemic: a lesson from history 100 years after 1918. J Prev Med Hyg 60(1):E64-E67. https://doi.org/10.15167/2421-4248/ jpmh2019.60.1.1205

Mercer A (2014) Infections, chronic disease, and the epidemiological transition: a new perspective. Boydell \& Brewer, Woodbridge

Mishra B (2015) Resurgence of influenza a (H1N1) 09: smoldering pandemic in India? J Global Infect Dis 7(2):56

Moathay D, Ramesh KV (2020) Binding site analysis of potential inhibitors of COVID 19 using AutoDock. VirusDisease 31:194-199. https://doi.org/10.1007/s13337-020-00585-z

Mourya DT, Yadav PD, Ulhas PT, Bharwaj SD (2019) Emerging/reemerging viral diseases and new viruses on the Indian horizon. Indian J Med Res 149:447-467

Muralidharan N, Sakthivel R, Velmurugan D, Gromiha MM (2020) Computational studies of drug repurposing and synergism of lopinavir, oseltamivir and ritonavir binding with SARS-CoV-2 protease against COVID-19. J Biomol Struct Dyn 14:1-6

Nair D, Neel SB (2020) Lack of collaboration slacking India's corona virus fight. Nat India https://doi.org/10.1038/nindia2020.50

Nicklin J, Graeme-Cook, Paget T, Killinton R (2002) Instant notes in microbiology. Vikas Books Pvt Ltd, New Delhi, pp 269-326
Nicola M, Alsafi Z, Sohrabi C, Kerwan A, Al-Jabir A, Iosifidis C, Agha M, Agha R (2020) The socio-economic implications of the coronavirus pandemic (COVID-19): a review. Int J Surgery (Lond Engl) 78:185-193. https://doi.org/10.1016/j.ijsu.2020.04.018

Ministry of Health and Family Welfare (2020) http://main.mofhw.gov.in/ Accessed on 15th May 2020

http://www.nanavatihospital.org Accessed 22/05/2020

http://content.time.com/time/specials/packages/completelist/ 0,29569,2027479,00.html. Accessed 15 June 2020

http://www.cbc.ca/news/technology/cholera-s-seven-pandemics-1. 758504. Accessed 15 June 2020

http://www.infoplease.com/cig/dangerous-diseases-epidemics/bubonicplague.html. Accessed 16 June 2020

http://www.who.int/csr/resources/publications/surveillance/plague.pdf. Accessed 25 May 2020

https://www.ids.ac.uk/opinions/lessons-from-brazil-for-the-globalresponse-to-covid-19/. Accessed 28 May 2020

https://www.mphonline.org/worst-pandemics-in-history/ Acessed on 25 May 2020

https://www.news-medical.net/medical/authors/angela-betsaidalaguipo Accessed on 28 May 2020

https://www.thehindubusinessline.com/economy/agri-business/strongimmunity-is-a-key-weapon-in-the-fight-against-covid-19/ article31453126.ece. Accessed 16 May 2020

http://www.worldometers.info/coronavirus/. Accessed on 22 May 2020

Pelczar MJ, Chan ECS, Kreg NR (1993) Microbiology. Tata Mc Graw Hill, New Delhi, pp 1-400

Paital B, Das K, Parida SK (2020) Inter nation social lockdown versus medical care against COVID-19, a mild environmental insight with special reference to India. Sci Total Environ 23:138914

Parija SC (2016) Textbook of microbiology and immunology. Elsevier India, Chennai

Patel AB, Verma A (2020) COVID-19 and angiotensin-converting enzyme inhibitors and angiotensin receptor blockers: what is the evidence? JAMA 323(18):1769-1770

Pevey HS, Rowe DR, Tchobanoglous G (2017) A text book of environmental engineering. Mc Graw Hill Education, New York, pp 1-20

Phillips H (2014) The recent wave of 'Spanish' flu historiography. Soc Hist Med 27(4):789-808

Page I (2020) COVID-19 and higher education: some issues. University News 58 p 23

Radusin M (2012a) The Spanish flu—part II: the second and third wave. Vojnosanit Pregl 69(10):917-927

Radusin M (2012b) The Spanish flu - part I: the first wave. Vojnosanit Pregl 69(9):812-817

Raj K, Rohit, Ghosh A et al (2020) Coronavirus as silent killer: recent advancement to pathogenesis, therapeutic strategy and future perspectives. VirusDisease. https://doi.org/10.1007/s13337-02000580-4

Ramteke L (2020) Impact of COVID-19 on child labour problem in India. EPRA Int J Multidiscip Res 6(6). https://doi.org/10.36713/epra2013

Rashid S, Labani S, Das BC (2016) Knowledge, awareness and attitude on HPV, HPV vaccine and cervical cancer among the college students in India. PLoS One 11(11):e0166713

Rauch S, Jasny E, Schmidt KEand Petsh B (2018) New vaccine technologies to combat outbreak situations. Front Immunal 9:1963. https:// doi.org/10.3389/fimmu.2018.01963

Reid AH, Taubenberger JK, Fanning TG (2004) Evidence of an absence: the genetic origins of the 1918 pandemic influenza virus. Nat Rev Microbiol 2(11):909-914

Rice AL, Sacco L, Hyder A, Black RE (2000) Malnutrition as an underlying cause of childhood deaths associated with infectious diseases in developing countries. Bull World Health Organ 78:1207-1221

Robert P (1959) Swaroop S, Burrows W. History of the disease. Cholera. World Health Organization, Geneva 11-50 
Robert P (1954) Cholera studies: 1. History of the disease. Bull World Health Organ 10(3):421

Sanders JM, Monogue ML, Jodlowski TZ, Cutrell JB (2020) Pharmacologic treatments for coronavirus disease 2019 (COVID19): a review. JAMA 323(18):1824-1836. https://doi.org/10.1001/ jama.2020.6019

Sarkar P, KDH L, Dhumal C, Panigrahi SS, Choudhary R (2015) Traditional and ayurvedic foods of Indian origin. J Ethnic Foods 2(3):97-109

Satyajeet N, Pramanik A (2009) HIV/Aids in India: stigmatisation as a process of communication and social relationship. Caudernos Info pp 115-117

Scheidel W (2017) The great Leveler: violence and the history of inequality from the stone age to the twenty-first century. Ch. 10. In: The black death. Princeton University Press, Princeton, pp 2911-2313

Shanks GD (2015) Insights from unusual aspects of the 1918 influenza pandemic. Travel Med Infect Dis 13(3):217-222. https://doi.org/10. 1016/j.tmaid.2015.05.001

Singh S (2020) Impact of COVID-19 pandemic on education system. Tathapi 19(26):58-63

Singhal T (2020) A review of coronavirus disease-2019 (COVID-19). Indian J Pediatr 13:1-6

Sivabakya TK, Srinivas G (2020) Will the antimalarial drug take over to combat COVID-19?. J Public Health (Berl). https://doi.org/10.1007/ s10389-020-01293-0

Suri JC, Sen MK (2011) Pandemic influenza-Indian experience. Lung India 28(1):2-4

Swetha G, Anantha Eashwar VM, Gopalakrishnan S (2019) Epidemics and pandemics in India throughout history: a review article. Indian J Public Health Res Dev 10(8):1570-1576

Taubenberger JK, Morens DM (2006) Influenza: the mother of all pandemics. Emerg Infect Dis 12(1):15-22

Tsoucalas G, Karachaliou F, Kalogirou V, Gatos G, Mavrogiannaki E, Antoniou A, Gatos K (2015) The first announcement about the 1918 "Spanish flu" pandemic in Greece through the writings of the pioneer newspaper "Thessalia" almost a century ago. Infez Med 23(1): 79-82

Vale RD, Dell K (2009) The biological sciences in India:aiming high for future. J cell Biol 184(3):342-353. https://doi.org/10.1083/jcb. 200812123

Vanita S (2020) Indian scientists wage frontline battle against corona virus. Nature India. https://doi.org/10.1038/nindia.2020.56. Published online 1 April 2020

Velavan TP, Mayer CG (2020) The COVID 19 Epidemic. Trop Med Int Health. 25:278-280. https://doi.org/10.1111/tmi.13383
Wever PC, Van Bergen L (2014) Death from 1918 pandemic influenza during the First World War: a perspective from personal and anecdotal evidence. Influenza Other Respir Viruses 8(5):538-546

WHO (2020) Coron virus disease (COVD 19), Situational report 59. WHO, Geneva accessed on 22nd May 2020

WHO Coronavirus (2020) http://www.who.int/health-topics/ coronavirus\#tab=tab_2 Accessed 22 May 2020

WHO Report (2007) Available at: http://www.who.int/csr/resources/ publications/swineflu/WHO_CD_EPR_2007_6/en/index.html. Accessed 29 March 2010

WHO Report (2009a) Guidelines for pharmacological management of pandemic (H1N1) 2009 influenza and other influenza viruses. http://www.who.int/csr/resources/publications/swineflu/h1n1_use antivirals_20090820/en/indx.html. Accessed 29 March 2010

WHO Report (2009b) Population fund, UNICEF, and the World Bank. Geneva, Switzerland, 2009. Available at: http:/www.who.int/ making_pregnancy_safer/documents/924159084x/en/index.html. Accessed 29 March 2010

WHO Report (2009c) Recommendations on pandemic (H1N1) 2009 vaccines. Available at: http:/www.who.int/csr/disease/swineflu/ notes/h1n1_vaccine_20090713/en/index.html. Accessed 29 March 2010

WHO Report (2010) Recommendations see breast feeding. World Health Organization, 2010. Available at: http://www.who.int/child adolescent_health/topics/prevention_care/child/nutrition/ breastfeedin/en/index.html. Accessed 29 March 2010

WHO Report (2014) Use of convalescent whole blood or plasma collected from patients recovered from Ebola virus disease for transfusion, as an empirical treatment during outbreaks. http://apps.who.int/iris/ rest/bitstreams/604045/retrieve

World Health Organisation (2020) Coronavirus disease 2019 (COVID19): situation report - 59. WHO, Geneva

Yaseen MA, Srinivas M, Steve W (2020) COVID-19: a novel coronavirus and a novel challenge for critical care, Intensive Care Med (2020) 46:833-836. https://doi.org/10.1007/s00134-020-05955-1

Zhou F, Yu T, Du R, Fan G, Liu Y, Liu Z, Xiang J, Wang Y, Song B, Gu X, Guan L (2020) Clinical course and risk factors for mortality of adult in patients with COVID-19 in Wuhan, China: a retrospective cohort study. Lancet 395(10229):1054-1062

Publisher's note Springer Nature remains neutral with regard to jurisdictional claims in published maps and institutional affiliations. 